\title{
Twentieth Anniversary of the European Group of Public Administration's Permanent Study Group on ICTs in Public Administration
}

In September 2006, at the European Group of Public Administration's (EGPA) Annual Conference at Bocconi University in Milan, the Permanent Study Group on informatisation in Public Administration celebrated its twentieth anniversary. What started as a small band of men at an EGPA Conference workshop on 'Effects of Technology on Administration' has grown into a strong, institutionalised network of European public administration scholars with a special interest in the introduction, management and use of Information and Communication Technologies (ICTs) in Public Administration, and their wider implications. Two decades later, an impressive legacy of conference papers, books and journal articles, as well as a leading international journal, demonstrate the success of the 'Informatisation' Study Group in building a substantial body of knowledge in a new topic field for public administration.

To celebrate this memorable occasion, a special event was organised where longstanding members of the Study Group, together with past and present Study Group Chairs and EGPA president Professor Geert Bouckaert, reflected upon the past, present and future of the Study Group's activities. Various Study Group members prepared reflective essays for this event, and these are presented in this Special Issue of Information Polity. Besides reflections on the unique character of this European Public Administration Study Group, such as the strong network and team spirit among Study Group members in developing a shared body of knowledge, the friendships developed over time, and the opportunities offered to young scholars, these contributions together present an interesting overview of strengths, weaknesses, opportunities and threats, a "SWOT-analysis", of twenty years of academic research and debate on ICTs in Public Administration.

First of all in this Special Issue, Founding Father of the Study Group Ignace Snellen shares his reflections with us on the question: "Is "Informatisation" after 20 years still a "corpus alienum" in Public Administration? His remembrances go back to the very first Study Group activity in Copenhagen: an extraordinary meeting where for instance one of the two papers prepared for this inaugural workshop was received with utter disbelief by the majority of workshop participants. This profound reaction however did not restrict the development of a fruitful European research programme on informatisation at the macro-, meso- and micro-levels of public administration. In his overview of academic outputs within each of these research streams, Snellen pays particular attention to the fundamental implications of changes happening at the micro-level of public administration as a result of informatisation. His explanation of the lack of interest of public administration scholars for these deep changes in policy implementation is the fact that public administration scholars are focused on the strategic aspects of 
public administration, such as politics and policy development, rather than the operational aspects of public administration.

In his contribution 'Reconstructing Public Administration Theory from Below' Klaus Lenk observes that, after more than fifty years of ICT use in public administration, and twenty years of informatisation research activities, public administration theory is still extremely reluctant to consider fundamental changes happening to the daily work of executive agencies as a result of ICTs. In Lenk's view not only the public administration discipline is to blame here as informatisation studies may have contributed themselves to their disconnected position from mainstream public administration and public policy research. He argues for instance that informatisation studies often have been overly impressed by the latest wave of technological products available. Moreover, theoretical efforts of informatisation scholars appear to jump quickly towards hypotheses about alleged characteristics and effects of "ICT" as if this concept involves a single set of technologies. According to Lenk, informatisation studies therefore have failed to develop a body of theory which takes into account both the technological potential behind the expression "ICT" and the changing world of government and governance.

To be able to bridge the gap successfully between research on information systems in public administration and public administration theory, Lenk advises that two black boxes be opened: firstly, the 'ICT' concept needs to be unpacked and deconstructed in a way that the range of technologies involved becomes visible; and secondly, the operational level of public administration needs to be opened up, with public administration theory facing the momentous task of a shift from institutionalism and structural thinking towards a process view of administrative praxis including the use of ICTs.

In his reflections on the past, present and future of Study Group activities John Taylor urges his EGPA Study Group colleagues towards 'Rediscovering the Grand Narratives of the Information Polity'. Taylor observes that, whereas in the early days of the Study Group collective thinking was being developed around three grand narrative themes, namely, informatisation, the information polity, and infocracy, in the last 10 years the collective sights of the Study Group were lowered to engagement with meso- and microthemes related to public management and system development and application. He encourages scholars working on the crossroads of ICTs and public administration to re-secure a distinctive perspective by rediscovering the broader themes of public administration, in good academic tradition of thoughtful and critical theorising and supported by empirical research.

Charles Raab's contribution on 'The EGPA Study Group at 20: Reflections Backwards, Forwards and Sideways' especially focuses on the particular interest Raab has had in the question of the privacy of personal data, and related values in the 'information society', during the lifetime of the Study Group. In the early 1990s, when Raab joined the Study Group, he found few colleagues who shared an interest in empirical and normative matters concerning privacy. Raab explains these distanced orientations as a result of the Study Group's research agenda paralleling governments' own agendas, with governments keen to reaping the administrative benefits of the ICT revolution at the time, such as increased efficiency and effectiveness. Another explanation is the Study Group's relative neglect of theorising and unpacking the black-box concept of 'information'. From the mid-1990s however, Raab observes an increased attention to wider information issues and questions, including privacy, both in government and in Study Group activities. Profound events like $9 / 11$ have pressed governments to focus predominantly on policy issues such as information sharing, personal identification and identity management, which make the Study Group's attention to privacy, and the study of the politics of privacy, most timely.

In his essay on 'The perspective of Janus', Frank Bannister reflects on the Study Group's past and future based on his personal experience and background. Having a strong computing background Bannister admits that his first EGPA Study Group experience was in fact a culture shock to him. Not only did he step 
into a new, public administration world of terminology and modes of thought, he also became introduced to the innovative concept of a 'permanent' Study Group. In Bannister's view, with E-Government having become the current academic flavour of the month, the distinctive value proposition of the EGPA Study Group is embedded in its 'permanent' character: as each annual Study Group meeting comprises members of many years standing as well as new faces who in time will provide continuity with the past, a collective memory and accumulated insights can be and has been developed which provides a fruitful platform for developing new, broader and deeper ideas on E-Government.

In his contribution 'Why don't they listen to us? Reasserting the role of ICT in Public Administration' Albert Meijer reflects on the impact of twenty years of research on informatisation in Public Administration, having been a member of the Study Group during the last 10 years. He points at the Study Group's limited success of influencing mainstream debates in public administration and the fact that other public administration scholars do not seem to be receptive for the Study Group's impressive range of research findings. Meijer sees explanations for this restricted impact in the public image of technology, the modesty of researchers, the difficulty of developing theories about continuing technological change, and the isolation that results from specialization. He presents various strategies for reasserting technology into mainstream public administration debates including the need to formulate catchy theories, to investigate established informatisation practices, to conduct comparative research, and to find a balance between specialization and integration in the study of ICTs within the public administration discipline.

Where Meijer has taken an 'inside out'-perspective to reflect on the Study Group's restricted impact on mainstream debates in public administration, Miriam Lips in her contribution 'Does Public Administration have artefacts?' has chosen an 'outside in' perspective to explore explanations for the blank spot in current scholarly and practitioners' activities of relating the use of ICTs in government to fundamental changes in public administration. She concludes that the dominance of the technical artefact in the attention for ICTs in public administration appears to have blindfolded scholars and practitioners towards a broader and deeper understanding of what is commonly called 'E-Government'. Taking Langdon Winner's story as a useful learning experience, public administration scholarship does not seem to have been sufficiently or critically engaged with E-Government as an important area of public sector reform, thus far.

After twenty years of strong academic activity, acknowledging its important scientific contribution, the SWOT-analysis for the Study Group on the basis of these reflective essays seems to mainly present weaknesses and threats. However, a complete SWOT-analysis tries to convert defined weaknesses and threats into opportunities and hopefully future strengths. An important final conclusion for the Study Group may be summarised by Geert Bouckaert's words at this special occasion: it is better to travel optimistically than to arrive. With its twentieth anniversary of collaborative academic study it is clear that the fellow travellers have not passed the finish line of their shared journey yet. What becomes clear in these various contributions on the past, present and future of informatisation research is for instance the strong and important agenda-setting role of this Study Group for the study of Public Administration. Both theoretically and empirically there appear to be no good reasons to end the life of this permanent Study Group therefore: on the contrary, increasingly being applied in a wide range of public administration processes and activities, it is clear that ICTs will enable changes in government and public administration. It is particularly through the lenses of public administration that we are able to explore and assess the proper meaning of these changes.

Miriam Lips $^{1}$

\footnotetext{
${ }^{1}$ Miriam Lips is Professor of E-Government at Victoria University of Wellington and Research Associate at the Oxford Internet Institute. E-mail: miriam.lips@vuw.ac.nz.
} 